\title{
Post-ruminal effects of rumen-protected methionine supplementation with low protein diet using long-term simulation and in vitro digestibility technique
}

\author{
Imtiaz Hussain Raja Abbasi ${ }^{1}$, Farzana Abbasi ${ }^{2}$, Mohamed E. Abd El-Hack ${ }^{3}$ Ayman A. Swelum ${ }^{4}$, Junhu Yao ${ }^{\text {* }}$
} and Yangchun $\mathrm{CaO}^{1 *}$

\begin{abstract}
Microbial degradation in the rumen and dietary availability of methionine amino acid have been reported as limiting in dairy ruminants. The aim of the present study was to examine the post-ruminal effects of feeding ruminants different concentrations of rumen-protected methionine (RPM) in low crude protein diets using the long-term rumen simulation method (Rusitec) followed by in vitro abomasum and ileum digestibility technique. The experiment contained four treatment groups: (1) high protein, without RPM supplementation (HP); (2) low protein, without RPM supplementation (LP); (3) low protein supplementation with low RPM (LPLM); and (4) low protein supplementation with high RPM (LPHM) mixed per $20 \pm 0.04 \mathrm{~g}$ basal diet in every fermenter. The results showed that the LPLM and LPHM groups had significantly higher disappearance of crude protein and neutral detergent fiber in the abomasum and ileum than the HP treatment $(P<0.05)$ and were the same as the LP group $(P>0.05)$. The proportions of short-chain fatty acids and total volatile fatty acids in the abomasum and ileum were the same between the LPHM and HP groups $(P>0.05)$; however, the LPLM group was found to be significantly $(P<0.05)$ lower than the HP group and similar to the LP group $(P>0.05)$. Rusitec $\mathrm{pH}$ before or after changing feed bags and daily ammonia nitrogen production in the abomasum and ileum were non significantly $(P>0.05)$ different among all groups. In conclusion, RPM supplementation with low crude protein diets promoted post-ruminal digestibility and production of volatile fatty acids.
\end{abstract}

Keywords: In-vitro digestibility, Methionine, Protein, Post-ruminal, Rusitec

\section{Introduction}

Proteins, specifically amino acids profiles, are the most limiting nutrient for milk production in ruminants with high genetic merit. To solve this problem, dietary supplementation with rumen-protected amino acids (RPAA) is a suitable approach (Elek et al. 2008; Osorio et al. 2013). The main objective of any nutritional program is to formulate diets that match the nutritional requirements of the animal to their age and stage. Moreover, it is important to promote the production of short-chain fatty acids

\footnotetext{
*Correspondence: yaojunhu2004@sohu.com; caoyangchun@126.com 1 College of Animal Science and Technology, Northwest A\&F University, Yangling 712100, Shaanxi, People's Republic of China
}

Full list of author information is available at the end of the article
(SCFAs), which are known as key bacterial metabolites, for synthesis by dietary carbohydrate fermentation in the gastrointestinal tract of animals (Tan et al. 2014). In ruminants, $70-80 \%$ of energy for the rumen epithelia and $50-70 \%$ for the overall energy requirements are provided by SCFAs and a variety of physiological functions are maintained by the rumen epithelium (Bergman 1990; Tufarelli et al. 2009). Furthermore, digestibility of nutrients is expressed as the amount that is absorbed by the body of an animal and the utilization of those nutrients for growth, reproduction, and other functions. Data suggest that dry matter intake (DMI) and digestibility of nutrients are major factors influencing nutrient utilization in dairy cattle, yet in lactating dairy cows, DMI is 
driven by the production of milk but sometimes limited by physical fill and metabolic effects (Allen 2000). Feed is a rich source of proteins; however, it is hard to digest and animals cannot maintain the amino acids (AA) balance between the high production of milk and supplementation of free AA and the balance of essential AA, which limits the key methyl donor, methionine, in dairy ruminants. In this situation, RPAA supplementation is a common method to counteract AA deficiency in dairy cow diets (Abbasi et al. 2018). The AA products are produced from ruminal fermentation and aim to enable maximum flow of AA concentrations in the small intestine. Supplementation of RPAA can increase the flow of AA in the duodenum and absorption also significantly promotes production performance in dairy cattle (Lara et al. 2006). Methionine is a sulfur AA that plays a major role in many pathways, e.g., synthesis of phospholipids, carnitine, creatine, and polyamines, and a source of the methyl donor S-adenosyl methionine (Abbasi et al. 2018). Moreover, methionine is also utilized for protein synthesis and can donate methyl groups for a different reaction and to deliver sulfur groups from the synthesis of cysteine. Therefore, it is important to balance and maintain all these methionine-dependent key functions in dairy ruminants via the supply of additional methionine into a protected form (i.e., rumen-protected methionine, RPM) for post-ruminal maximum absorption, particularly in the small intestine. In many studies, methionine has been reported as being one of the most important AA required for growth of small and large ruminants (Wiese et al. 2003). It is involved in many vital metabolic processes including serving as a glycogenic AA (Brosnan 2003), as a precursor to cysteine, and as a constituent of various vital proteins, e.g., glutathione peroxidase and apolipoprotein B-100 (Brosnan 2003). Additionally, methionine also plays a direct role in low density lipoprotein synthesis in bovines and decreases plasma ketones during early lactation (Girard and Matte 2005; Abbasi et al. 2017). Elevating blood plasma methionine levels might promote better liver function, increase antioxidant levels, decrease inflammation, and improve oxidative stress capacity (Osorio et al. 2013). If maximum degradation of methionine in the rumen or free supply occurs, then this causes a limitation of methionine in dairy ruminants. Therefore, a negative methyl donor balance is also a significant challenge for peripheral dairy cows. Several techniques have been developed to ensure the proper supply of methionine including encapsulation or matrix protection of methionine (Patton 2010) into the diets of ruminants to balance energy by increasing glucose production, promote hepatic oxidation of AA, or directly endorse protein synthesis.
Our hypothesis was that rumen-protected DL-methionine was degraded more slowly by rumen microorganisms, moderately in the abomasum, and fully in the small intestine of the ruminant, thereby providing a steadier supply of methionine to the small intestine. Thus, the main purpose of the present study was to examine the effects of feeding different levels of rumen-protected DL-methionine supplementation with low crude protein $(\mathrm{CP})$ on post-ruminal fermentation, disappearance, production of volatile fatty acids, and ammonia nitrogen $\left(\mathrm{NH}_{3}-\mathrm{N}\right)$ production.

\section{Materials and methods}

\section{Animal care}

Care of animals and all experimental procedures in the study were permitted by the Institutional Animal Care and Use Committee (IACUC) of the College of Animal Science and Technology of the Northwest A\&F University (Yangling, Shaanxi, PR China).

\section{Simulation apparatus and test product}

The experiment was performed by the application of the rumen simulation technique (Rusitec; Sanshin, Tokyo, Japan) as designated by Kajikawa et al. (2003) and in vitro digestibility was undertaken based on the modified technique by Boisen and Fernhndez (1995). The test product was manufactured by Mepron ${ }^{\circledR}$ (Degussa Corporation, Germany) as a sample of a surface-coated, carbohydrate-protected product. The pellets contained a core of methionine that was coated with numerous fine layers of ethyl-cellulose and stearic acid. The final product was composed of a minimum 85\% DL-methionine, approximately $8.5 \%$ carbohydrates in non-structural form, 3.5\% neutral detergent fiber (NDF), 1.5\% ash, 1.0\% moisture, and $0.5 \%$ crude fat.

\section{Inoculum donor and experimental diets}

Four healthy Xinong Saanen goats [average initial body weight $(55.6 \pm 1.40 \mathrm{~kg})]$, were used for inoculum. Rumen content was collected through the ruminal fistula after 4:00 h morning feeding into pre-heated at $39{ }^{\circ} \mathrm{C}$ flasks and transferred to the laboratory. The Rusitec experiment designed randomly and conducted over two independents 15 days incubation periods with 7 days for adaption and 8 days for samples collection. The four groups were as follows: (1) high protein without RPM (HP, $163.39 \mathrm{~g} /$ kg CP), (2) low protein without RPM (LP, $146.33 \mathrm{~g} /$ $\mathrm{kg} \mathrm{CP})$, (3) low protein ( $141.80 \mathrm{~g} / \mathrm{kg} \mathrm{CP})$ supplemented with low concentration of RPM $(0.11 \mathrm{~g} / \mathrm{kg}$ DM) (LPLM), and (4) low protein $(143.30 \mathrm{~g} / \mathrm{kg} \mathrm{CP})$ supplemented with high concentration of RPM (0.81 g/kg DM) (LPHM). HP diet formulated as a positive control group based on NRC (2001) recommendation and LP was designed as a 
negative control group shown in Table 1. Diets were formulated by using the Cornell-Penn-Miner Dairy (CPMDairy, Version 3.0.8.1) Software and balanced according to NRC (2001) requirements. In vitro, one step abomasum and ileum digestibility were followed by the modified procedure of Boisen and Fernhndez (1995), by utilizing undigested Rusitec residue for abomasum digestibility, and for further ileum digestibility, the abomasum residue was utilized.

\section{Experimental technique and sampling}

After collection, the inoculum was strained through four layers of cheese cloth maintained under anaerobic conditions. On day 1, each Rusitec fermenter was filled with $350 \mathrm{~mL}$ strained liquid inoculum and an equivalent volume of McDougall's buffer solution based on the procedure described by McDougall (1948). One nylon bag containing $70 \pm 0.05 \mathrm{~g}$ of solid rumen digesta (wet weight) and one nylon bag containing $20 \pm 0.04 \mathrm{~g}$ of the experimental diet comprising roughage and concentrate (45:55 DM basis), which was ground and then sieved

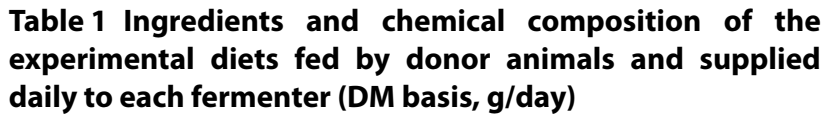

\begin{tabular}{|c|c|c|c|c|}
\hline \multirow[t]{2}{*}{ Items } & \multicolumn{4}{|c|}{ Treatments } \\
\hline & $\mathrm{HP}$ & LP & LPLM & LPHM \\
\hline \multicolumn{5}{|l|}{ Ingredients supply (g/day) } \\
\hline Corn silage & 3.65 & 3.87 & 3.87 & 3.87 \\
\hline Alfalfa hay & 2.03 & 0.78 & 0.78 & 0.78 \\
\hline Wheat straw & 3.06 & 4.28 & 4.27 & 4.27 \\
\hline Ground corn & 3.25 & 4.33 & 4.33 & 4.33 \\
\hline Wheat bran & 1.56 & 0.94 & 0.94 & 0.93 \\
\hline Soybean meal & 1.41 & 2.01 & 2.01 & 2.01 \\
\hline Cottonseed meal & 1.92 & 0.76 & 0.76 & 0.76 \\
\hline Corn germ meal & 2.31 & 2.11 & 2.11 & 2.11 \\
\hline Limestone & 0.21 & 0.18 & 0.18 & 0.18 \\
\hline Dicalcium phosphate & 0.00 & 0.10 & 0.10 & 0.10 \\
\hline $\mathrm{NaCl}$ & 0.21 & 0.24 & 0.24 & 0.24 \\
\hline $\mathrm{NaHCO}_{3}$ & 0.04 & 0.04 & 0.04 & 0.04 \\
\hline Premix ${ }^{a}$ & 0.36 & 0.36 & 0.36 & 0.36 \\
\hline RPM & 0.0000 & 0.0000 & 0.0021 & 0.0200 \\
\hline \multicolumn{5}{|l|}{ Chemical composition } \\
\hline Dry matter (g/day) & 9.03 & 8.90 & 8.92 & 8.94 \\
\hline Crude protein (g/day) & 1.63 & 1.42 & 1.42 & 1.43 \\
\hline aNeutral detergent fiber (g/day) & 4.71 & 4.72 & 4.71 & 4.70 \\
\hline Acid detergent fiber (g/day) & 2.12 & 2.11 & 2.05 & 2.12 \\
\hline Ether extract (g/day) & 0.29 & 0.28 & 0.28 & 0.28 \\
\hline Gross energy (MJ/day) & 0.16 & 0.16 & 0.16 & 0.17 \\
\hline
\end{tabular}

a Premix (contains): $9.80 \mathrm{mg} \mathrm{Zn,} 10.5 \mathrm{mg} \mathrm{Cu}, 12.00 \mathrm{mg} \mathrm{Mn}, 0.32 \mathrm{mg} \mathrm{l}, 0.15 \mathrm{mg}$ Se, $0.11 \mathrm{mg} \mathrm{Co}, 500 \mathrm{IU}$ vitamin D3, 40 IU vitamin E, and $2500 \mathrm{IU}$ vitamin A, per kilogram of TMR on DM basis through 4 and $2 \mathrm{~mm}$ sieves, were added to the fermenters. After $24 \mathrm{~h}$, the bag containing the solid inoculum was swapped with a new feed bag in each fermenter. The next day, the old bag was replaced with a new one; therefore, each experimental bag was incubated for $48 \mathrm{~h}$. Freshly prepared artificial saliva (McDougall's buffer) was continuously imbued into each Rusitec fermenter through a pump at a flow rate of $626 \mathrm{~mL} /$ day following the methods described by Kajikawa et al. (2003). After completion of the adaptation period, on day 8,9 , and 10 , the $\mathrm{pH}$ of each fermenter was measured before exchanging the feed bag. On day 11 and 12 after substituting the feed bag from each fermenter, $6 \mathrm{~mL}$ of fluid was used to measure $\mathrm{pH}$ at $0,3,6,9,12,18,21$, and $24 \mathrm{~h}$, respectively.

On days 13, 14, and 15, one feed bag (containing residue) from every Rusitec fermenter was collected, washed with $100 \mathrm{~mL}$ of McDougall's buffer followed by a cold rinse cycle for $10 \mathrm{~min}$ with cold water and dried in an air forced oven for $24 \mathrm{~h}$ at $65^{\circ} \mathrm{C}$ for further in vitro abomasum digestibility.

Disappearance of DM and other indexes were calculated as (g/kg DM):

$$
\text { Disappearance }=\left[\left(\mathrm{W}_{3}-\mathrm{W}_{4}\right) / \mathrm{W}_{3}\right] \times 1000
$$

where, $\mathrm{W}_{3}$ is the \% DM in the feed sample $\left[\left(\mathrm{W}_{1}-\mathrm{W}\right) \times \mathrm{DM} \%\right] ; \mathrm{W}_{4}$ is the residue $\mathrm{DM}$ weight $\left[\mathrm{W}_{2}-\mathrm{W}\right] \times 100 ; \mathrm{W}$ is the weight of the empty bag; $\mathrm{W}_{1}$ is the weight of the bag with feed sample before incubation; and $\mathrm{W}_{2}$ is the weight of the bag with residue after incubation.

\section{In vitro digestibility (abomasum and ileum)}

Boisen and Fernhndez (1995) introduced a threestep procedure which was further modified into twosteps by using incubation of the samples with pepsin enzyme, and then further incubation carried out with small intestinal fluid for $18 \mathrm{~h}$. The small intestine fluid was collected and prepared according to Liang (2013). After incubation of experimental feed into Rusitec, the undigested residue was dried at $65{ }^{\circ} \mathrm{C}$ and weighed $2.50 \pm 0.04 \mathrm{~g}$ DM basis into $100 \mathrm{~mL}$ bottles (8 replicates per treatment) for in vitro abomasum digestibility with $6 \mathrm{~h}$ incubation by automatic incubactor and shaker. Furthermore, after incubation at abomasum, the contents were filtered through two layers of cheese cloth, the residue was dried at $65^{\circ} \mathrm{C}$ and weighted $0.60 \pm 0.05 \mathrm{~g}$ DM basis pour into $100 \mathrm{~mL}$ bottles with $10 \mathrm{~mL}$ of fluid from abomasum and $30 \mathrm{~mL}$ of artificial saliva were added with same replication for in vitro ileum digestibility. Incubation was carried out for $18 \mathrm{~h}$ in an automatic incubactor and shaker, contents were filtered fluid and undigested residue (abomasum and ileum) were collected for further analysis. 


\section{Chemical analysis}

All the dried feed, residues from post-ruminal (abomasum and ileum) incubation were mixed thoroughly following experimental groups with treatment and ground to pass a 1-mm screen in a Wiley mill for use in chemical analyses. The samples were analyzed for dry matter (DM) content (method 934.01; AOAC 2004), ether extract (EE, method 920.30; AOAC International 2004) and crude protein (CP) (method 988.05; AOAC International 2004). Neutral detergent fiber (aNDF) and acid detergent fiber (ADF) were resolute by Van Soest et al. (1991) method, using an $\mathrm{ANKOM}^{200}$ fiber analyzer (Ankom Technology, USA). Using the reagents and filter bags recommended by the manufacturer Ankom Technology, USA. Further, at analysis was conducted with a heat stable $\alpha$-amylase with sodium sulfite and expressed as inclusive residual ash. When collecting Rusitec fermenter fluid, $\mathrm{pH}$ was measured quickly by portable $\mathrm{pH}$ meter (Orion 230 A-plus, Thermo Scientific, Beverly, MA, USA). The concentrations of volatile fatty acids (VFA) was quantified using a gas chromatography according to Zhao et al. (2010), (model 663-30, Hitachi Corporation, Tokyo, Japan). The aliquot for the analysis of ammonia- $\mathrm{N}$ was measured according to the method described (Russi et al. 2002).

\section{Statistical analysis}

Differences of in vitro measurements were analyzed by in one-way ANOVA procedure (SAS Inc., Cary, NC, USA) version SPSS 19.0 (SPSS Inc., Chicago, IL, USA) to test the differences among treatments. The least square means and standard error of means were presented. Differences among treatments means were separated by Tukey's test, and the significance level was stated at $P<0.05$.

\section{Results}

Ingredients and chemical composition of the experimental diets

The recommended feeding level of RPM depends on the deficiency of the AA in the diet as well as dairy ruminant requirements as defined by the NRC (2001). The present study evaluated the post-ruminal (abomasum-ileum) effects of different supplementation levels of RPM with low protein on digestibility, volatile fatty acids, $\mathrm{NH}_{3}-\mathrm{N}$, and total tract digestibility using the Rusitec and in vitro techniques. The formulated experimental diets and their chemical compositions are presented in Table 1. The chemical compositions showed that the CP of the HP group was higher than the other groups.

\section{Rumen-protected methionine supplements their effects on disappearance}

Different levels of RPM supplement with low CP diets, their effect on disappearance indexes of the abomasum and ileum were shown in Tables 2, 3 respectively. The disappearance of $\mathrm{DM}$, ether extract (EE), gross energy (GE) and ADF was unaffected in overall treatments $(P>0.05)$ at abomasum and ileum. However, $\mathrm{CP}$ disappearance was significantly higher $(\mathrm{P}<0.05)$ in the treatment group (LPLM; LPHM) than HP and parallel $(P>0.05)$ with LP group. Although, NDF disappearance was found significantly $(P<0.05)$ higher in LPHM group than HP but parallel $(P>0.05)$ with LPLM and LP group at both abomasum and ileum.

\section{Rusitec $\mathrm{pH}$ and post-ruminal ammonia-nitrogen production}

Effects of RPM supplement on Rusitec fermenter $\mathrm{pH}$ and post-ruminal ammonia-nitrogen $\mathrm{NH}_{3}-\mathrm{N}$ were presented in Table 4 . The $\mathrm{pH}$ values before feeding and after feeding

Table 2 Low dietary protein supplemented with rumen-protected methionine effects on disappearance at abomasum using in vitro digestibility technique (means; $n=4)$

\begin{tabular}{|c|c|c|c|c|c|c|}
\hline \multirow[t]{2}{*}{ Substrate disappearance } & \multicolumn{4}{|c|}{ Treatments } & \multirow[t]{2}{*}{ SEM } & \multirow[t]{2}{*}{$P$ value } \\
\hline & HP & LP & LPLM & LPHM & & \\
\hline Dry matter (g/kg DM) & 242.92 & 250.92 & 252.89 & 259.55 & 6.22 & 0.85 \\
\hline Crude protein (g/kg DM) & $517.92^{b}$ & $557.18^{\mathrm{a}}$ & $560.53^{\mathrm{a}}$ & $566.53^{\mathrm{a}}$ & 6.45 & 0.01 \\
\hline Neutral detergent fiber (g/kg DM) & $174.10^{b}$ & $178.61^{\mathrm{a}, \mathrm{b}}$ & $179.37^{\mathrm{a}, \mathrm{b}}$ & $182.47^{\mathrm{a}}$ & 1.01 & 0.03 \\
\hline Acid detergent fiber (g/kg DM) & 136.60 & 129.10 & 130.31 & 135.21 & 2.61 & 0.73 \\
\hline Gross energy (MJ/kg DM) & 314.72 & 311.22 & 314.73 & 315.74 & 4.79 & 0.99 \\
\hline
\end{tabular}

SEM standard error of the mean

a,b Superscripts values within the same row, are significantly different at $(P<0.05)$ 
from $0,3,6,9,12,15,18,21$ to 24 h of supplemented groups (LPLM and LPHM) were found similar $(P>0.05)$ to LP and HP control groups. Although the supplementation of methionine did not significantly effect on $\mathrm{NH}_{3}-\mathrm{N}$, the concentration of $\mathrm{NH}_{3}-\mathrm{N}$ production was found nonsignificant $(P>0.05)$ among supplemented LPLM, LPHM and control HP and LP group at abomasum and ileum.
Effect of supplements with low CP on total and individual volatile fatty acids

The concentration of molar proportions of the daily production of total and individual VFA in the abomasum and ileum are shown in Tables 5 and 6, respectively. No significant differences in the daily production of acetate, propionate, and butyrate were found between LPHM and HP groups; however, significant differences were

Table 3 Low dietary protein supplemented with rumen-protected methionine effects on disappearance at ileum portion using in vitro digestibility technique (means; $n=4)$

\begin{tabular}{|c|c|c|c|c|c|c|}
\hline \multirow[t]{2}{*}{ Substrate disappearance } & \multicolumn{4}{|c|}{ Treatments } & \multirow[t]{2}{*}{ SEM } & \multirow[t]{2}{*}{$P$ value } \\
\hline & $\mathrm{HP}$ & LP & LPLM & LPHM & & \\
\hline Dry matter (g/kg DM) & 474.41 & 473.34 & 476.38 & 480.87 & 3.41 & 0.89 \\
\hline Crude protein (g/kg DM) & $774.40^{b}$ & $907.58^{\mathrm{a}}$ & $871.90^{a}$ & $875.45^{\mathrm{a}}$ & 14.49 & $<0.01$ \\
\hline Neutral detergent fiber ( $\mathrm{g} / \mathrm{kg}$ DM) & $400.13^{b}$ & $418.75^{\mathrm{a}, \mathrm{b}}$ & $420.41^{a, b}$ & $424.08^{a}$ & 3.30 & 0.02 \\
\hline Acid detergent fiber (g/kg DM) & 345.44 & 351.88 & 358.39 & 354.44 & 4.48 & 0.81 \\
\hline Gross energy (MJ/kg DM) & 517.85 & 507.97 & 511.44 & 518.66 & 3.93 & 0.77 \\
\hline
\end{tabular}

SEM standard error of the mean

$\mathrm{a}, \mathrm{b}$ Superscripts values within the same row, are significantly different at $(P<0.05)$

Table 4 Effects of rumen-protected methionine supplementation with low dietary protein on the post-ruminal production of $\mathrm{NH}_{3}-\mathrm{N}$ and Rusitec $\mathrm{pH}$ using a rumen simulation technique and in vitro digestibility technique (means; $\left.n=4\right)$

\begin{tabular}{|c|c|c|c|c|c|c|}
\hline \multirow[t]{2}{*}{ Items } & \multicolumn{4}{|c|}{ Treatments } & \multirow[t]{2}{*}{ SEM } & \multirow[t]{2}{*}{$P$ value } \\
\hline & $\mathrm{HP}$ & LP & LPLM & LPHM & & \\
\hline pH before feeding ${ }^{a}$ & 6.60 & 6.65 & 6.62 & 6.64 & 0.01 & 0.83 \\
\hline $\mathrm{pH}$ after feeding $(0-24 \mathrm{~h})^{\mathrm{a}}$ & 6.65 & 6.68 & 6.37 & 6.73 & 0.01 & 0.20 \\
\hline Abomasum $\mathrm{NH}_{3}-\mathrm{N}(\mathrm{mg} / 100 \mathrm{~mL})$ & 5.72 & 4.45 & 4.95 & 5.78 & 0.27 & 0.24 \\
\hline Ileum $\mathrm{NH}_{3}-\mathrm{N}(\mathrm{mg} / 100 \mathrm{~mL})$ & 16.27 & 15.06 & 15.91 & 16.23 & 0.59 & 0.93 \\
\hline
\end{tabular}

Values within the same row are different at $(P<0.05)$

SEM standard error of the mean

a Rusitec pH value

Table 5 Low dietary protein with rumen-protected methionine supplementation effects on daily production of total and individual volatile fatty acids using an in vitro abomasum digestibility technique (means; $\mathbf{n}=4$ )

\begin{tabular}{|c|c|c|c|c|c|c|}
\hline \multirow[t]{2}{*}{ Items } & \multicolumn{4}{|c|}{ Treatments } & \multirow[t]{2}{*}{ SEM } & \multirow[t]{2}{*}{$P$ value } \\
\hline & $\mathrm{HP}$ & LP & LPLM & LPHM & & \\
\hline Total VFA (mM) & $52.81^{\mathrm{a}}$ & $45.07^{b}$ & $48.74^{a, b}$ & $51.92^{\mathrm{a}}$ & 1.23 & 0.03 \\
\hline Acetate (mM) & $29.79^{a}$ & $25.34^{b}$ & $27.97^{a, b}$ & $29.07^{a, b}$ & 0.70 & 0.04 \\
\hline Propionate (mM) & $11.8^{\mathrm{a}}$ & $9.74^{b}$ & $10.40^{a, b}$ & $11.72^{\mathrm{a}}$ & 0.36 & 0.04 \\
\hline Isobutyrate (mM) & 0.43 & 0.41 & 0.38 & 0.41 & 0.01 & 0.76 \\
\hline Butyrate (mM) & $6.76^{a}$ & $6.17^{b}$ & $6.30^{b}$ & $6.64^{a}$ & 0.09 & 0.00 \\
\hline Isovalerate (mM) & 1.33 & 1.47 & 1.40 & 1.44 & 0.04 & 0.81 \\
\hline Valerate (mM) & 2.70 & 1.94 & 2.29 & 2.63 & 0.13 & 0.11 \\
\hline Acetate:propionate ratio & 2.52 & 2.60 & 2.69 & 2.48 & 0.03 & 0.05 \\
\hline
\end{tabular}

VFA volatile fatty acids, SEM standard error of the mean

a,b Superscripts values within the same row are significantly different at $(P<0.05)$ 
Table 6 Low dietary protein with rumen-protected methionine supplementation effects on daily production of total and individual volatile fatty acids using an in vitro ileum digestibility technique $($ means; $\mathbf{n = 4 )}$

\begin{tabular}{lllllll}
\hline Items & \multicolumn{2}{l}{ Treatments } & & SEM & P value \\
\cline { 2 - 5 } & HP & LP & LPLM & LPHM & \\
\hline Total VFA (mM) & $29.18^{\mathrm{a}}$ & $23.02^{\mathrm{b}}$ & $24.44^{\mathrm{b}}$ & $28.26^{\mathrm{a}}$ & 0.98 & 0.00 \\
Acetate (mM) & $19.78^{\mathrm{a}}$ & $16.14^{\mathrm{b}}$ & $17.20^{\mathrm{b}}$ & $19.31^{\mathrm{a}}$ & 0.57 & 0.00 \\
Propionate (mM) & $4.92^{\mathrm{a}}$ & $4.05^{\mathrm{b}}$ & $4.29^{\mathrm{b}}$ & $4.82^{\mathrm{a}}$ & 0.14 & 0.00 \\
Isobutyrate (mM) & 0.04 & 0.03 & 0.03 & 0.03 & 0.00 & 0.15 \\
Butyrate (mM) & $2.74^{\mathrm{a}}$ & $1.77^{\mathrm{b}}$ & $1.87^{\mathrm{b}}$ & $2.46^{\mathrm{a}}$ & 0.00 \\
Isovalerate (mM) & 0.57 & 0.43 & 0.45 & 0.59 & 0.03 & 0.11 \\
Valerate (mM) & $1.13^{\mathrm{a}}$ & $0.59^{\mathrm{b}}$ & $0.60^{\mathrm{b}}$ & $1.04^{\mathrm{a}}$ & 0.09 & 0.00 \\
Acetate:propionate ratio & 4.02 & 3.98 & 4.00 & 4.00 & 0.02 & 0.96 \\
\hline
\end{tabular}

VFA volatile fatty acids, SEM standard error of the mean

a,b Superscripts values within the same row are significantly different at $(P<0.05)$

found between LPLM and LP groups in the abomasum and ileum $(P<0.05)$. The production of total VFA was linearly improved $(P<0.05)$ with LPHM supplementation that were found to be similar $(P>0.05)$ to HP and significantly higher than LPLM and LP groups $(P<0.05)$. However, only the production of valerate in the ileum was found to be the same between the LPHM and HP groups $(P>0.05)$ and was significantly higher than the LPLM and LP groups $(P<0.05)$.

\section{Discussion}

Mammals are depending on macro and micronutrients for the regulation of physiological functions, health, production, and the prevention of diseases (Abbasi et al. 2014; Stover et al. 2017). Amino acids are natural compounds in many of the aforementioned biological courses (He et al. 2011). Methionine is a sulphur-containing AA that plays a key position in many pathways, i.e. synthesis of phospholipids, carnitine, creatine, polyamines, phosphatidylcholine, precursor of succinyl-CoA, homocysteine, cellular methylation (Soares et al. 2017), deliver sulphur groups for the synthesis of cysteine and reduce dietary cysteine requirement (Mackay et al. 2012). The present study was designed to measure which concentration of RPM with low dietary CP effects maximum postruminal, to help for further application in vivo study. For maximum VFA production, disappearance and essential AA at ileum to maintain dairy performance and solve environmental problems linked to high protein feeding in ruminant's industry.

In the current study, RPM supplementation significantly promotes disappearance and fermentation of diets, as the concentration increases from 0.11 and $0.81 \mathrm{~g} / \mathrm{kg}$ (DM basis). The post-ruminal disappearance of $\mathrm{CP}$ and aNDF were significantly higher in LPLM and LPHM, but no effects were found on DM, ADF, and GE with RPM supplementation. Like our current findings, previously reported that dry matter intake averaged $25.4 \mathrm{~kg} /$ day was not affected by RPM treatment (Zang et al. 2006). Consistent with these results, in other trials it was observed no DMI improvement through supplementing RPM (Lee et al. 2015). A DMI response to RPAA supplementation was recorded negligible in studies with early-lactation cows (Lara et al. 2006). Conversely, Lodman et al. (1990) recorded a numerical improvement in the extent and rate of DM and NDF digestion, because of urea and methionine supplementation. The post-ruminal production of total VFA was improved significantly, particularly, SCFAs, (acetate, propionate, and butyrate) were significantly improved by supplementation of RPM. Our findings support earlier observations that, the SCFAs, primarily acetate, propionate, and butyrate, are organic acids produced in the intestinal lumen by bacterial fermentation of mainly undigested dietary carbohydrates, specifically resistant starch and dietary fiber and, to a lesser extent, dietary and endogenous proteins (Fan et al. 2015). However, it was noted that propionate originating from fermentation is the major precursor of glucose in cows which contributes up to $60 \%$ of glucose flux rate (Larsen and Kristensen 2013). For ruminants, glucose is the important source of milk lactose synthesis. It is mostly provided by the liver (up to 90\%) through gluconeogenesis process (Nafikov and Beitz 2007). Furthermore, Mulligan et al. (2002) stated that both total VFA and synthesis of acetate associated with a NDF degradability. However, in current study, at ileum the production of valerate was significantly increased with high supplementation of RPM, the results was similar to previous study of Mackie et al. (1991), who reported that, with supplementation of DL-Met the significant increase in iso-valerate and valerate observed which contributed to a greater total VFA, because of branched-chain VFA (Leu, 
Ile, Val) originates from the bacterial deamination moreover, greater branched-chain VFA indicates that methionine analog supplements increased the hydrolysis of protein. The $\mathrm{pH}$ plays a significant role to maintain normal homeostasis of the gastrointestinal tract. Maximum and balance $\mathrm{pH}$ is important for normal digestibility of experimental diets in simulation apparatus. The $\mathrm{NH}_{3}-\mathrm{N}$ concentration in the Rusitec effluent depends on the degradation and $\mathrm{N}$ uptake efficiency by post ruminal microorganism, and production of $\mathrm{NH}_{3}-\mathrm{N}$ play the main role in MCP synthesis (Bach et al. 2005). In the present study, the post-ruminal concentration of $\mathrm{NH}_{3}-\mathrm{N}$ was unaffected significantly by RPM supplementation compared to the control groups. However, previous studies indicating that ammonia absorption $(0.9 \mathrm{~g} /$ day with the silage diet $)$ occurred between the rumen and duodenum and probably from the omasum (Engelhardt and Hauffe 1975). Ammonia that entered the ileum was mostly absorbed before the digesta reached the ileum (Siddons et al. 1985). Results indicated that RPM supplementation did not significantly alter the Rusitec fermenter $\mathrm{pH}$ before changing experimental feed or after changing from 0 to $24 \mathrm{~h}$ compared to the control group. The result agreed with Papas et al. (1984) who reported that, rumen-protected methionine was $94 \%$ stable in acetate buffer $\mathrm{pH} 5.4$ in the rumen, however, polymeric coatings are usually $\mathrm{pH}$-sensitive and intended to maintain their structural integrity at the $\mathrm{pH}$ normally encountered in the rumen, furthermore, in citrate buffer $\mathrm{pH} 2.9$, which simulates the abomasal environment, and $90 \%$ of methionine was released. The lower $\mathrm{pH}$ of the post ruminal (abomasum and ileum) activates the breakdown of the coating and consenting release of amino acids for absorption. Furthermore, the current finding supported by Silva et al. (2016) who reported that dietary $\mathrm{CP}$ levels not altered ruminal $\mathrm{pH}$ in finishing beef cattle. The discrepancy between the in vivo and in vitro three-step procedure estimates may partly be due to the protein digestion, RPM supplementation and post-ruminal effects (Calsamiglia and Stern 1995). Moreover, another cause of the discrepancy between the in vivo and in vitro three-step procedure might be the incubation time in the Rusitec.

In conclusion, different levels of ethyl-cellulose RPM supplemented with low $\mathrm{CP}$ and their post-ruminal effects showed that the LPHM group promoted disappearance, improved fermentation, increased post-ruminal fiber degradation, and promoted the total tract digestibility of nutrients. Future research should proceed in vivo to address the mechanism involved in producing such effects by RPM supplementation and the way that oxidative status might affect subsequent reproductive and productive performance of dairy ruminants.
Authors' contributions

IHRA main performer of this study, Professor JHY, and YCC conceived the idea of the study, reviewed and approved the final manuscript. IHRA and Professor YCC wrote the article. MEAE-H and AAS critically read, revised, and improved the article, while FA helped in the analysis. All authors read and approved the final manuscript.

\section{Author details \\ ${ }^{1}$ College of Animal Science and Technology, Northwest A\&F University, Yangling 712100, Shaanxi, People's Republic of China. ${ }^{2}$ School of Life Science and Engineering, Southwest University of Science and Technology, Mian- yang 621010, Sichuan, People's Republic of China. ${ }^{3}$ Department of Poultry, Faculty of Agriculture, Zagazig University, Zagazig 44511, Egypt. ${ }^{4}$ Department of Animal Production, College of Food and Agriculture Sciences, King Saud University, P.O. Box 2460, Riyadh 11451, Saudi Arabia.}

\section{Acknowledgements}

All authors thank their universities for their help in accomplishing this work. Author (Abbasi IHR) express sincere appreciation to Professor Cao Yangchun for his ideas, guidance, co-supervision of Doctorate work and helped for provisions of rumen-protected methionine (Mepron ${ }^{\circledR}$ ) from Evonik Degussa GmbH (Germany).

\section{Competing interests}

The authors declare that they have no competing interests.

Availability of data and materials

Not applicable.

\section{Consent for publication}

Not applicable.

\section{Ethics approval and consent to participate}

Care of animals and all experimental procedures in the study were permitted by the Institutional Animal Care and Use Committee (IACUC) of the College of Animal Science and Technology of the Northwest A\&F University (Yangling, Shaanxi, PR China).

\section{Funding}

The work was partially supported by the National Key Research and Development Program of China (award numbers: 2017YFD0500500), National Natural Science Foundation of China (award numbers: 31472122 and 31672451) and Collaborative Innovation Major Project of Industry, University, Research, and Application in Yangling Demonstration Zone (award numbers: 2016CXY-18).

\section{Publisher's Note}

Springer Nature remains neutral with regard to jurisdictional claims in published maps and institutional affiliations.

Received: 5 February 2018 Accepted: 3 March 2018

Published online: 09 March 2018

\section{References}

Abbasi IHR, Sahito HA, Abbasi F, Menghwar DR, Kaka NA, Sanjrani MI (2014) Impact of different crude protein levels on the growth of lambs under intensive management system. Int J Adv Res 2:227-235

Abbasi IHR, Abbasi F, Soomro RN, Abd El-Hack ME, Abdel-Latif M, Li W, Hao R, Sun F, Bodinga BM, Hayat K, Yao JH, Cao YC (2017) Considering choline as methionine precursor, lipoproteins transporter, hepatic promoter and antioxidant agent in dairy cows. AMB Express 7:214

Abbasi IHR, Abbasi F, Abd El-Hack ME, Abdel-Latif M, Soomro RN, Hayat K, Mohamed MAE, Bodinga BM, Yao JH, Cao YC (2018) Critical analysis of excessive utilization of crude protein in ruminants ration: impact on environmental ecosystem and opportunities of supplementation of limiting amino acids - a review. Environ Sci Poll Res 25(1):181-190

Allen MS (2000) Effects of diet on short-term regulation of feed intake by lactating dairy cattle. J Dairy Sci 83:1598-1624 
AOAC International (2004) Official methods of analysis of AOAC International. Pages v (loose-leaf). AOAC International, Arlington

Bach AS, Calsamiglia S, Stern MD (2005) Nitrogen metabolism in the rumen. J Dairy Sci 88:E9-E21

Bergman EN (1990) Energy contributions of volatile fatty acids from the gastrointestinal tract in various species. Physiol Rev 70:567-590

Boisen S, Fernhndez JA (1995) Prediction of the apparent ileal digestibility of protein and amino acids in feedstuffs and feed mixtures for pigs by in vitro analyses. Anim Feed Sci Technol 51:39-41

Brosnan JT (2003) Interorgan amino acid transport and its regulation. J Nutr 133:2068-2072

Calsamiglia S, Stern MD (1995) A three-step in vitro procedure for estimating intestinal digestion of protein in ruminants. J Anim Sci 73:1459-1465

Elek P, Newbold JR, Gaal T, Wagner L, Husveth F (2008) Effects of rumen-protected choline supplementation on milk production and choline supply of periparturient dairy cows. Animal 2:1595-1601

Engelhardt VW, Hauffe R (1975) In: McDonald IW, Warner ACI (eds) Digestion and metabolism in the ruminant. University of New England Publishing Unit, Armidale, pp 216-30

Fan P, Li L, Rezaei A, Eslamfam S, Che D, Ma X (2015) Metabolites of dietary protein and peptides by intestinal microbes and their impacts on the gut. Curr Protein Pept Sci 16:646-654

Girard CL, Matte JJ (2005) Folic acid and vitamin B12 requirements of dairy cows: a concept to be revised. Livest Prod Sci 98:123-133

He Q, Yin Y, Zhao F, Kong X, Wu G, Ren P (2011) Metabonomics and its role in amino acid nutrition research. Front Biosci Landmark 16(26):2451-2460

Kajikawa H, Jin H, Terada F, Suga T (2003) The operation, and characteristics of newly improved and marketable artificial rumen (Rusitec), vol 2. National Institute of livestock and grassland science, Tsukuba, pp 1-30

Lara A, Mendoza GD, Landois L, Barcena R, Sanchez-Torres MT, Rojo R, Ayala J, Vega S (2006) Milk production in Holstein cows supplemented with different levels of ruminally protected methionine. Livest Sci 105:105-108

Larsen M, Kristensen NB (2013) Precursors for liver gluconeogenesis in periparturient dairy cows. Animal 7(10):1640-1650

Lee C, Giallongo F, Hristov AN, Lapierre H, Cassidy TW, Heyler KS, Varga GA, Parys C (2015) Effect of dietary protein level and rumen-protected amino acid supplementation on amino acid utilization for milk protein in lactating dairy cows. J Dairy Sci 98:1885-1902

Liang C (2013) Study on the in vitro method to predict the digestibility of energy and crude protein of feeds in pigs using the simulative digestion system. Ph.D. Thesis, Chinese Academy of Agriculture Sciences, China

Lodman DW, Petersen MK, Clark CK, Wiley JS, Havstad KM, McInerney MJ (1990) Substitution of DL-methionine for soybean meal as a winter supplement for gestating cows grazing native range. J Anim Sci 68(12):4361-4375

Mackay DS, Brophy JD, Mcbreairty LE, Mcgowan RA, Bertolo RF (2012) Intrauterine growth restriction leads to changes in sulfur amino acid metabolism, but not global DNA methylation. Yucatan miniature piglets. J Nutr Biochem 23(9):1121-1127

Mackie RI, White BA, Bryant MP (1991) Lipid metabolism in anaerobic ecosystems. Crit Rev Microbiol 17:449-479

McDougall E (1948) Studies on ruminant saliva. I. The composition and output of sheep's saliva. Biochem J 43(1):99-109

Mulligan FJ, Caffrey PJ, Rath M, Callan JJ, Brophy PO, Mara FP (2002) An investigation of feeding level effects on digestibility in cattle for diets based on grass silage and high fiber concentrates at two forages: concentrate 431 ratios. Livest Sci 77:311-323
Nafikov RA, Beitz DC (2007) Carbohydrate and lipid metabolism in farm animals. J Nutr 137(3):702-705

National Research Council (NRC) (2001) Nutrient requirements of dairy cattle, 7th rev edn. Natl. Acad. Press, Washington, DC

Osorio JS, Ji P, Drackley JK, Luchini D, Loor JJ (2013) Supplemental Smartamine M or MetaSmart during the transition period benefits postpartum cow performance and blood neutrophil function. J Dairy Sci 96:6248-6263

Papas AM, Sniffen CJ, Muscato TV (1984) Effectiveness of rumen-protected methionine for delivering methionine postruminally in dairy cows. J Dairy Sci 67:545-552

Patton R (2010) Effect of rumen-protected methionine on feed intake, milk production, true milk protein concentration, and true milk protein yield, and the factors that influence these effects: a meta-analysis. J Dairy Sci 93:2105-2118

Russi JP, Wallace RJ, Newbold CJ (2002) Influence of the pattern of peptide supply on microbial activity in the rumen simulating fermenter (RUSITEC). Br J Nutr 88:73-80

Siddons RC, Nolan JV, Beever DE, MacRae JC (1985) Nitrogen digestion and metabolism in sheep consuming diets containing contrasting forms and levels of N. Br J Nutr 54:175-187

Silva LDD, Pereira OG, Silva TCD, Valadares Filho SC, Ribeiro KG (2016) Effects of silage crop and dietary crude protein levels on digestibility ruminal fermentation, nitrogen use efficiency, and performance of finishing beef cattle. Anim Feed Sci Technol 220:22-33

Soares MS, Oliveira PS, Debom GN, DaSilveira MB, Polachini CR, Baldissarelli J, Morsch VM, Schetinger MR, Tavares RG, Stefanello FM, Spanevello RM (2017) Chronic administration of methionine and/or methionine sulfoxide alters oxidative stress parameters and ALA-D activity in liver and kidney of young rats. Amino Acids 49(1):129-138

Stover PJ, Durga J, Field MS (2017) Folate nutrition and blood-brain barrier dysfunction. Curr Opin Biotechnol 44:146-152

Tan J, McKenzie C, Potamitis M, Thorburn AN, Mackay CR, Macia L (2014) The role of short-chain fatty acids in health and disease. Adv Immunol 121:91-119

Tufarelli V, Dario M, Laudadio V (2009) Milk yield and composition of lactating Comisana ewes fed total mixed rations containing nitrogen sources with different ruminal degradability. Livest Sci 122:349-353

Van Soest PJ, Robertson JB, Lewis BA (1991) Methods for dietary fiber, neutral detergent fiber, and non-starch polysaccharides in relation to animal nutrition. J Dairy Sci 74:3583-3597

Wiese S, White C, Masters D, Milton J, Davidson R (2003) The growth performance and carcass attributes of Merino and Poll Dorset Merino lambs fed rumen-protected methionine (Smartamine TM-M). Crop Pasture Sci 54:507-513

Zang Y, Saed SS, Phipps ZC, Tager LR, McFadden JW, Krause KM (2006) Comparative effects of multiple sources of rumen-protected methionine on milk production and serum amino acid levels in mid-lactation dairy cows. Prof Anim Sci 33:692-699

Zhao XH, Zhang T, Xu M, Yao JH (2010) Effects of physically effective fiber on chewing activity, ruminal fermentation, and digestibility in goats. J Anim Sci 89:501-509

\section{Submit your manuscript to a SpringerOpen ${ }^{\circ}$ journal and benefit from:}

- Convenient online submission

- Rigorous peer review

- Open access: articles freely available online

- High visibility within the field

- Retaining the copyright to your article

Submit your next manuscript at $\boldsymbol{\nabla}$ springeropen.com 